\title{
速度依存ダンパーをもつ木質架構の振動台実験 \\ SHAKING TABLE TESTS OF WOOD FRAMES WITH VELOCITY-DEPENDENT DAMPERS
}

\author{
坂田弘安*1，笠井和彦*2，和田＼cjkstart章*3，緑川光 正*4，大木洋司*5 \\ 中川 徹*6, 松田和 浩*7 \\ Hiroyasu SAKATA, Kazuhiko KASAI, Akira WADA, Mitsumasa MIDORIKAWA, \\ Yoji OOKI, Toru NAKAGAWA and Kazuhiro MATSUDA
}

\begin{abstract}
Passive control schemes to mitigate seismic damage of wood houses are discussed. Extensive shaking table tests are conducted for various full-size wood-frame specimens. This paper focuses on the specimens with velocity-dependent dampers, and compares their dynamic properties and performance with those of conventional wood frame as well as passively controlled frame utilizing deformation-dependent dampers. Dynamic properties are defined by equivalent periods and damping ratios. Performance is assessed by referring to story drifts, accelerations, base shear forces, damper deformations and forces, and connection deformations. Test results are also predicted by proposed simplified rules based on the dynamic properties and response spectra.
\end{abstract}

Keywords: shaking table test, wood-frame, passive control, viscoelastic damper, response spectrum 振動台実験、木質架構、パッシブ制振、粘弹性ダンパー、応答スペクトル

1.はじめに

我国には既存不適格戸建木造住宅が全国に多数存在している。地 震時における人命確保に向けた既存不適格建物の而震補強のみなら ず、財産保持という観点からすると新築戸建木造住宅においてもよ り高い耐震性能が求められる。一方で、補助金制度があるにもかか わらず耐震補強などが普及していない現状があり、その理由の一つ として、耐震化メニューの少なさが挙げられる。住宅の耐震性向上 を活性化させるためにも、パッシブ制振技術を耐震化の選択肢の一 つとして導入する合理的方法を検討することは重要である。

筆者らが文献 1 で言及したように、木質構造に対する制振ダンパ 一適用に関寸る研究は多く行われるようになってきている。これま での研究結果を概観すると制振ダンパーに粘弾性体を用いたものの 研究が最も多い。その理由としては、粘弾性ダンパーは小変形から 大変形までの広い範囲の振動に対して堿衰効果を発揮できること、 面材に貼付寸るなど容易に作成することができること、小型で安価 なものとすることが可能であること、等が背景にあると考えられる。 その中で、筆者らは様々な履歴特性をもつ制振壁を開発・提案し、 強制変形加振などによりその有效性を検討してきた ${ }^{1)}$, 2)。また、2 層木造軸組住宅の一部をモデル化した実大の木質架構に対して、変 位依存ダンパーからなる制振壁や筋かい・構造用合板からなる既存 形式の耐力壁を組み込んだ試験体の振動台実験を行うことにより、 それらの動的特性の比較検討を行った ${ }^{3)}$ 。本報では、速度依存ダン パーからなる制振壁を組み込んだ試験体の振動台実験に関して報告 する。このように、様々な履歴特性を持つ多数のダンパーを用いた
振動台実験を行っている研究例は少なく、それらが地震時に木質住 宅に及ぼす影響に関して、減衰等の特性を把握するような検討はさ れていない。

そこで、以下の 2 点を目的として本研究を実施した。(1)速度依存 ダンパーからなる制振壁を用いた試験体に関して、文献 3 と同様の 形式で振動台実験を行うことにより、その基本的な動的挙動を把握 する。すなわち、破壊性状、応答変位、層せん断力、局所の挙動、 エネルギー吸収能力および等価周期と等価減衰等の変動特性を把握 する。(2)文献 3 で報告した既存の耐力壁・変位依存ダンパーによる 制振壁および本報で報告する速度依存ダンパーによる制振壁の特性 の違いを比較検討する。

\section{2. 実験概要}

\section{1 実験の概念と試験体の設定}

図 1 に示すように、試験体の基本形状は文献 3 と同様である。す なわち、強度等級 E95F315 の集成材を用い(柱に用いたスプルース集 成材は、曲げヤング係数 9.3GPa、曲げ強度 48.3MPa)、芯線で 1 辺が $2730 \mathrm{~mm}$ の箱型試験体に対して中央構面には壁要素を配置し、外側 構面は層せん断力をほとんど負担しない形状となっている。

壁倍率 2 をもつ壁要素が $2 \mathrm{P}(\mathrm{P}=0.91 \mathrm{~m})$ 存在する場合を標準と定 めたため、標準耐力は $7.13 \mathrm{kN}$ となる(付録 1)。1 層階高中央以上の 総重量は $35.7 \mathrm{kN}$ となるようにおもりの量を決定しており、それは標 準地震層せん断力係数 0.2 との積が標準耐力となるようにしている。 また、おもりの配置は柱の長期圧縮力を考慮して決定した。
*1 東京工業大学建築物理研究センター 准教授・工博

*2 東京工業大学建築物理研究センター 教授. Ph. D

*3 東京工業大学建築物理研究センター 教授・ 工博

*4 北海道大学 教授. 工博

*5 東京工業大学建築物理研究センター- 助教

*6 大林組

*7 東京工業大学 大学院生
Assoc. Prof., Struct. Eng. Res. Center, Tokyo Institute of Technology, Dr. Eng Prof., Struct. Eng. Res. Center, Tokyo Institute of Technology, Ph. D. Prof., Struct. Eng. Res. Center, Tokyo Institute of Technology, Dr. Eng. Prof., Hokkaido University, Dr. Eng.

Research Assoc., Struct. Eng. Res. Center, Tokyo Institute of Technology Obayashi Corporation Graduate Student, Tokyo Institute of Technology 


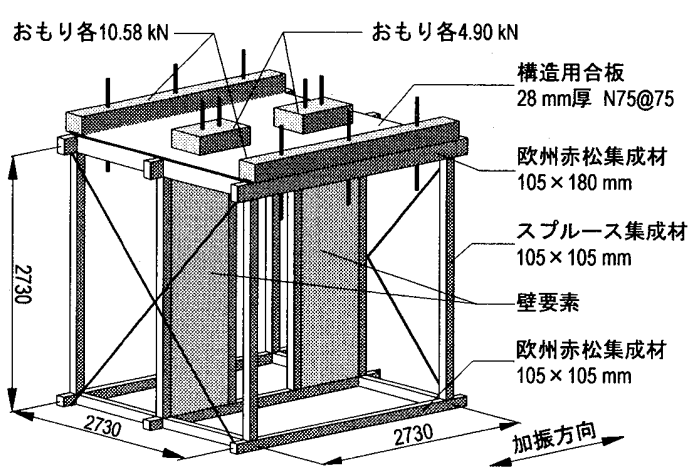

図 1 試験体概要

\section{2 試験体の概要}

試験体一覧を表 1 に示す。表中の壁量とは、各壁要素の壁倍率に その長さを乗じたものの和と定義する。壁要素の種類と配置が異な る計 4 体の試験体を用いた。各試験体に関し以下に述べる。なお、 試験体名の V は粘弾性ダンパー(Viscoelastic)、P は合板型架構 (Plywood)、K は K 型架構、B は方杖型架構(Brace)、WP は構造用合 板(Wood Panel)を意味する。

（1）壁要素を全て制振壁とした試験体

・VP-VP : 壁倍率 5 以上の粘弹性ダンパー合板型 ${ }^{1)} 2 \mathrm{P}$ 配置した 試験体。柱脚には柱両側のホールダウンと片側の 1 枚ハンチ型金物 2 個を併用し、柱頭には 1 枚ハンチ型金物を 2 個用いた。

- VK-VK : 壁倍率 5 以上の粘弾性ダンパーK 型 ${ }^{2)} 2 \mathrm{P}$ 配置した試 験体。柱脚にはブレースと一体のホールダウンと内使い $\mathrm{L}$ 型金物 2 個を併用した。柱頭には内使い L 型金物を 2 個用いた。

（2）制振壁と既存耐力壁を混合させた試験体

・VK-WP : 粘弹性ダンパーK 型を $1 \mathrm{P}$, 構造用合板を $1 \mathrm{P}$ ずつ配置 した試験体。WP 部は 1P あたり壁倍率 3 の構造用合板 2 級 $9 \mathrm{~mm}$ 厚 (釘 CN50, 外周部@100mm, 中間部@200mm)である。VK 部の詳細は 前述と同一である。

・VB-VB(WP) : 壁倍率 2 の粘弾性ダンパー方杖型を両側に $2 \mathrm{P}$, 構 造用合板を中央に $1 \mathrm{P}$ 配置した試験体。VB 部の柱脚・柱頭には内使 い $\mathrm{L}$ 型金物 2 個を用いた。WP 部の詳細は前述の通りである。

なお、振動台実験の前に各ダンパー構面 1P の試験をそれぞれ強 制变形加振によって検証した。その詳細は文献 1,2 で示したが、そ れらの文献で触れていない VB 架構に関してのみ、架構の詳細およ び強制変形加振実験結果を付録 2 に示す。

\section{3 粘弾性ダンパーの種類}

本研究では、図 2 のような履歴特性を持つ 2 種の粘弹性体を採用 した。VP-VP・VK-VK・VK-WP 試験体には自己接着性を有するア

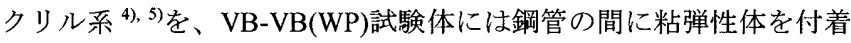
させなければならないため、溶着型のイソブチレン・スチレン系のを 用いた。2 種の材料の履歴特性に関して以下に記述する。

アクリル系の粘弾性体は応力一歪曲線が楕円となり、低温または 高振動になるにつれ楕円の傾きと面積、つまり剖性とエネルギー吸 収が増加する。このように温度、振動数によって決まる楕円の形状 は小振幅の加振ではサイクル数に関わらず一定であり、かつ棈円の 大きさが振幅に比例するという線形挙動が得られる。一方、大振幅 では非線形挙動を示し、1 サイクル目から歪の増加に伴い棈円の傾 きが低下し、後続波で更に低下する。

イソブチレン・スチレン系の粘弾性体は、小振幅で楕円、大振幅
表 1 試験体一覧

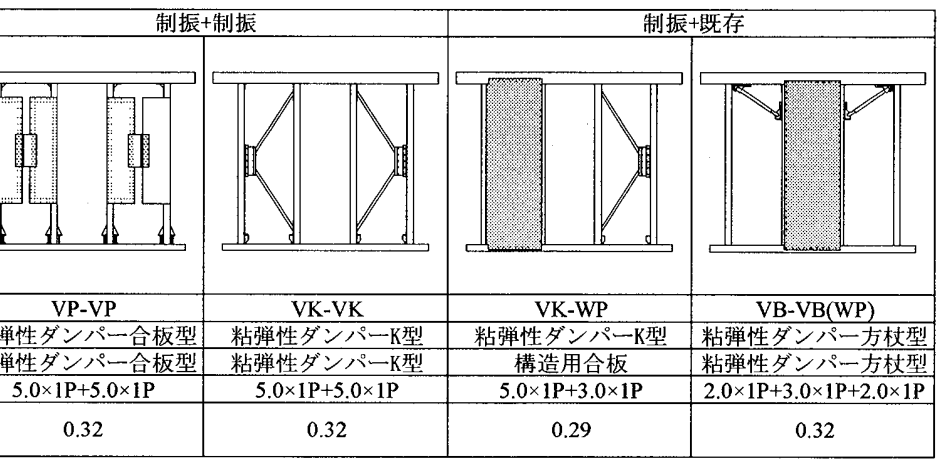

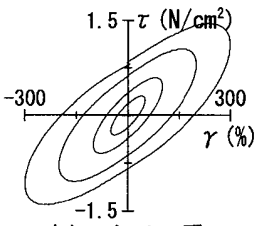

(a) アクリル系

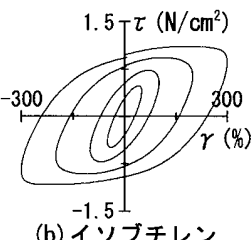

(b) イソブチレン ・スチレン系

図 2 タンパーの 応力ー歪関係

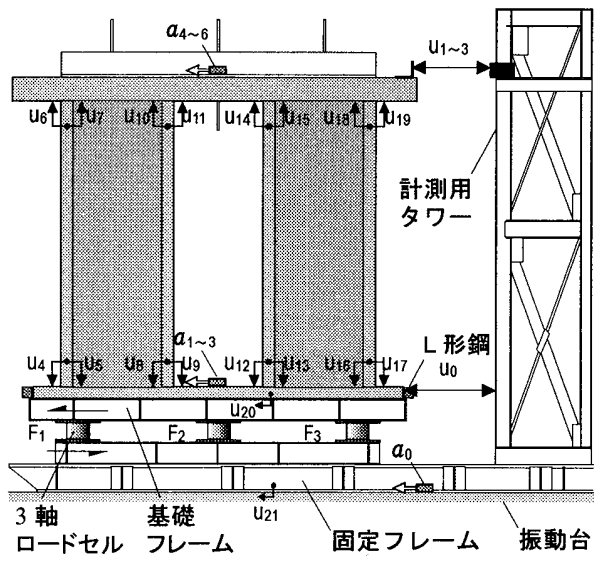

図 3 試験体設置・計測位置

でバイリニア型の履歴を示す特徵をもち、これにより、ダンパーの 支持部材一入力される力を過大にすることなく、なおかつエネルギ 一吸収を大きくする効果がある。また、貯蔵剛性や損失剛性の温度 依存性が小さく、十分な変形能力を有している。

\section{4 試験体設置・計測方法}

試験体設置と計測に関しても文献 3 と同様の形式で行った(図 3)。 すなわち、振動台上に設置した剛な計測用タワーに変位計を設置し $\left(u_{0} \sim u_{3}\right)$ 、梁と土台の木口面の相対変位を計測することで層閒変形を 算出した。振動台、核構面の土台 - 梁の中央部には加速度計を配置 $し\left(a_{0} \sim a_{6}\right)$ 、試験体の質量から層せん断力 $F$ を算出した。これらの計 測により、試験体土台・基礎フレーム・固定フレーム間のずれ、試 験体のねじれが発生していないことも確認した。

柱顕・柱脚には 1 箇所あたりに $2 つ の$ 変位計を柱芯位置から左右 にずらした位置に設置することで $\left(u_{4} \sim u_{19}\right)$ 、柱頭・柱脚の引き抜け 量および回転量を算出した。引き奇せ金物のボルトにはロードセル を取りつけてボルト軸力の変動を、 $\mathrm{K}$ 型ブレース・方杖の鋼管部には 歪グージを貼付してダンパー力を 計測した。サンプリング周波数は 0.001 秒である。

\section{5 入力加振波}

表 2 に入力加振波一覧を示す。 使用した波は 1968 八戸波 NS, 1952 Taft 波 EW, $1995 \mathrm{JMA}$ 神户波 NS であるが、それぞれに対して 最大加速度が表 2 右列の值となる ように基準化して用いた。なお、

表 2 入力加振波一覧

\begin{tabular}{|c|c|c|}
\hline No. & Name & $\mathrm{Acc}_{\max }(\mathrm{g})$ \\
\hline 1 & W1 & 0.1 \\
\hline 2 & $0.281(1-3)$ & 102 \\
\hline 3 & W2 & 0.1 \\
\hline 6 & $0.2 \mathrm{yTaft}$ & 02 \\
\hline 5 & W3 & 0.1 \\
\hline 6 & 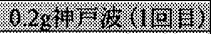 & 0.2 \\
\hline 7 & W4 & 0.1 \\
\hline 8 & 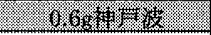 & 0.6 \\
\hline 9 & W5 & 0.1 \\
\hline 10 & 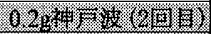 & 0.2 \\
\hline 11 & W6 & 0.1 \\
\hline 12 & 0.6 T Tar & 0.0 \\
\hline 13 & W7 & 0.1 \\
\hline
\end{tabular}

ホワイトノイズ波（gは重力加速度） 
VP-VP 試験体のみ $0.6 \mathrm{~g}$ 神户波が目標に対して $13 \%$ 程度小さく、 0.6gTaft 波では $20 \%$ 程度大きく入力される結果となった。地震波の 前後には最大加速度 $0.1 \mathrm{~g}$ のホワイトノイズ波を入力することで、微 小変形時における試験体の動的特性の変化を把握した。なお、粘弾 性ダンパーは全て加振前の温度を $20^{\circ} \mathrm{C} に$ 統一して加振を行った。

\section{3. 全体応答}

\section{1 層間変形の時刻歴応答と挙動の概要}

図 4 に、全試験体の $0.2 \mathrm{~g}$ 神戸波( 1 回目)、0.6g 神戸波、 $0.2 \mathrm{~g}$ 神戸 波(2 回目)の入力による層間変形 $u$ の時刻歴を示す。図中の破線は層 間変形角 $\theta=1 / 120 \mathrm{rad}$.を示す。

VP-VP 試験体と VK-VK 試験体は、 $0.2 \mathrm{~g}$ 神戸波(1 回目)の入力に対 し、 $\theta=1 / 120 \mathrm{rad}$.以内に留まった。これは、粘弾性ダンパーが $0.2 \mathrm{~g}$ の入力において十分に機能したためと考えられる。0.6g 神戸波で VP-VP 試験体は $\theta=1 / 100 \mathrm{rad}$ 、VK-VK 試験体は $\theta=1 / 71 \mathrm{rad}$. と変形し たが、外観上の損傷は確認できず、残留変形も見られなかった。そ の後の $0.2 \mathrm{~g}$ 神戸波 $(2$ 回目)の入力に対しては、両試験体とも 1 回目 とほぼ同形状の波形を示したことから、0.6 神戸波の入力において も架構の損傷はほとんど無いと言える。

VK-WP 試験体は、 $0.2 \mathrm{~g}$ 神戸波(1 回目)の入力に対し $\theta=1 / 120 \mathrm{rad}$. 以内に留まった。 $0.6 \mathrm{~g}$ 神戸波の入力に対し $\theta=1 / 46 \mathrm{rad}$.変形したが、 外観上の損傷は確認できなかった。しかし、0.2 神戸波(2回目)の入 力に対し、 $0.2 \mathrm{~g}$ 神戸波( 1 回目)と比較して周期が伸びていることから、 合板の釷が緩み剛性が低下したと考えられる。そのため、1 回目に 比べ変形も大きくなったものの、 $\theta=1 / 120 \mathrm{rad}$.程度に留まった。

VB-VB(WP)試験体は、 $0.2 \mathrm{~g}$ 神戸波( 1 回目)の入力に対して、他の 制振壁に比べ目標壁量が少ないため変形が大きいものの、 $\theta=1 / 120$ rad.以内に留まった。0.6g 神戸波に対して、合板が完全に浮き上が り、釬が抜けたため、層間変形は大きく、 $\theta=1 / 22 \mathrm{rad}$.変形した。こ のため $0.2 \mathrm{~g}$ 神戸波(2 回目)の入力に対して、壁要素が粘弾性ダンパ 一方杖型のみとなり、周期が伸びるとともに大きく変形した。

\section{2 層せん断力と層間変形の関係}

図 5 に、入力地震波に対する層せん断力と層間変形の関係を示す。 図中破線は $\theta=1 / 120 \mathrm{rad}$.に相当する変位を示す。また、表 3 に事前 に行った架構実験より得た壁倍率をもとに算出した試験体の壁量評
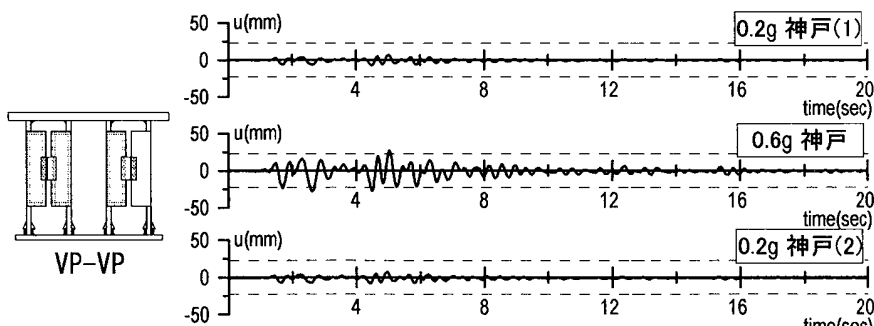

\begin{tabular}{|c|c|c|c|c|c|c|c|c|}
\hline No. & 試験体 & $\begin{array}{c}\text { 壁量 } * 1 \\
\text { 評洒值 }(\mathrm{m}) \\
\end{array}$ & $\begin{array}{c}\text { 壁量※2 } \\
\text { 実験值 }(\mathrm{m})\end{array}$ & $\begin{array}{c}\text { 必要 } \\
\text { 壁長 }(\mathrm{m})\end{array}$ & $\begin{array}{l}\mathrm{F}_{1 / 120} \\
(\mathrm{kN})\end{array}$ & $\begin{array}{l}\mathrm{F}_{\max } \\
(\mathrm{kN})\end{array}$ & $\begin{array}{c}a_{\max } \\
(\mathrm{g})\end{array}$ & $\begin{array}{r}\mathrm{u}_{\max } \\
(\mathrm{mm})\end{array}$ \\
\hline 1 & VP-V & 9.1 & 12.7 & 3.8 & 22.7 & 26.9 & 0.71 & 29.5 \\
\hline 2 & VK-I & 9.1 & 12.7 & 3.8 & 22.6 & 28.9 & .77 & 39.1 \\
\hline 3 & VK-WP & 7.3 & 11.9 & 3.8 & 21.3 & 32.0 & 0.87 & 59.0 \\
\hline 4 & VB-VB(WP & 6.4 & 8.6 & 3.8 & 15.3 & 26.8 & 0.82 & 120.7 \\
\hline
\end{tabular}

※2 壁量実験値は最初に 1/120rad.に達した時の層せん断力から算出
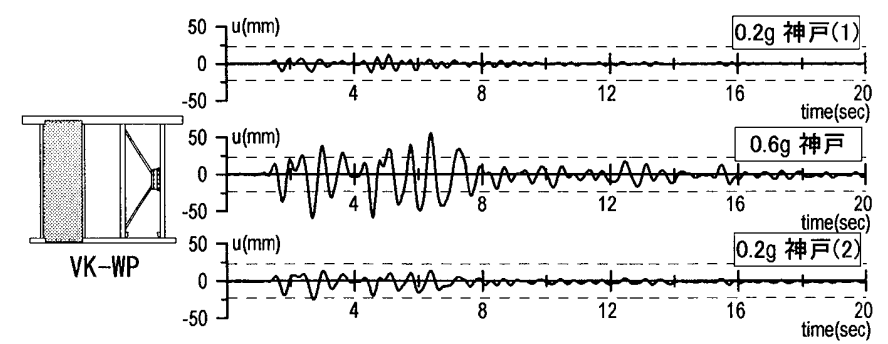
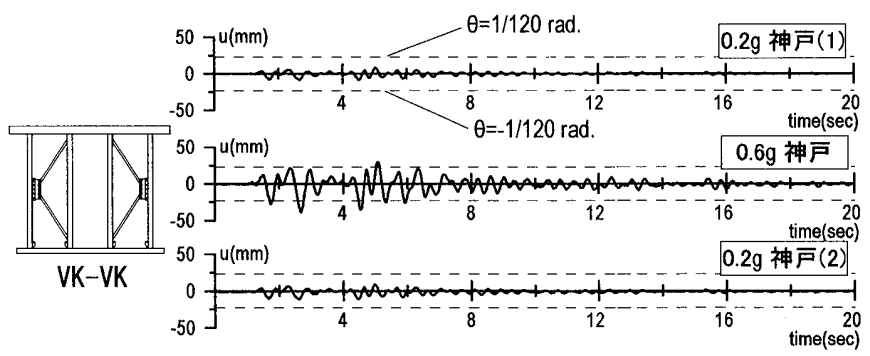

※1 1P の強制変形加振実験から求めた壁倍率 ${ }^{12}{ }^{27}$ から算出

価值、本試験体の重さに対して標準地震層せん断力係数を 0.2 とし て設計したときに必要とされる壁長、および $0.6 \mathrm{~g}$ 神戸波までの入力 から得た壁量実験值と $\theta=1 / 120 \mathrm{rad}$.時の耐力 $F_{1 / 120}$, 最大層せん断 力 $F_{\max }$, 最大応答加速度 $a_{\max }$,および最大層間変形 $u_{\max }$ を示す。

まず、制振壁のみの試験体について述べる (図 5 上段)。制振壁の 壁量実験值は全て壁量評価値を上回り (表 3)、目標とする耐力を得る ことが容易であることが分かる。VP-VP 試験体と VK-VK 試験体を 比較すると、VP-VP の等価剛性がやや大きい。これは、VP-VP の柱 波に対し棈円の履歴を示した。文献 3 の変位依存ダンパー制振試験 体に比べ層せん断力が低いことからも、小振幅の入力に対して速度 依存ダンパーが有効であることが分かる。 $0.6 \mathrm{~g}$ 神戸波では $0.2 \mathrm{~g}$ の各 3 波に比べ等価剛性がやや低いが、これは粘弾性体が損傷したから ではなく、温度上昇によるものである。これは、 $0.2 \mathrm{~g}$ 神戸波(2 回目) で 1 回目と同形状の履歷を示していることからも明らかである。

次に、制振壁と既存耐力壁の両方をもつ試験体について述べる (図 5.下段)。VK-WP 試験体は、WP 部の剛性が VK 部に比べて低い ためVK-VKに比べ等価剛性は低くなったが、0.2g の各 3 波に対し て $\theta=1 / 120 \mathrm{rad}$. 以内に留まった。また、 $0.6 \mathrm{~g}$ 神戸波では構造用合板 に打ちつけた釘に緩みが生じるため、その履歴は棈円の履歷にスリ ップが足された形状を示した。 $0.2 \mathrm{~g}$ 神戸波(2 回目)では、合板の釷が 緩むことから等価剛性は低くなるも $\theta=1 / 120 \mathrm{rad}$.程度に留まった。

VB-VB(WP)試験体は、0.2g の各 3 波に対し、他の制振試験体に比 べ壁量が小さいため変形は大きくなったが $\theta=1 / 120 \mathrm{rad}$.程度に留ま った。0.6g 神戸波では構造用合板が浮き上がり、 $\theta=1 / 22 \mathrm{rad}$.と大き

\section{表 $30.6 \mathrm{~g}$ 神戸波入力時の層せん断力と層間変形の最大值と壁量}

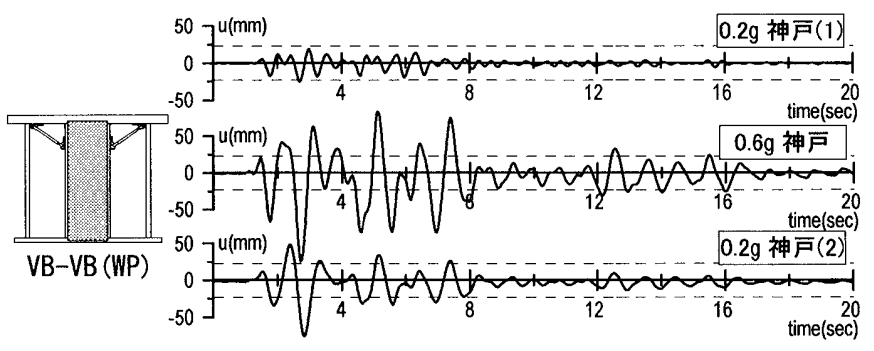

図 4 層間変形の時刻歴 


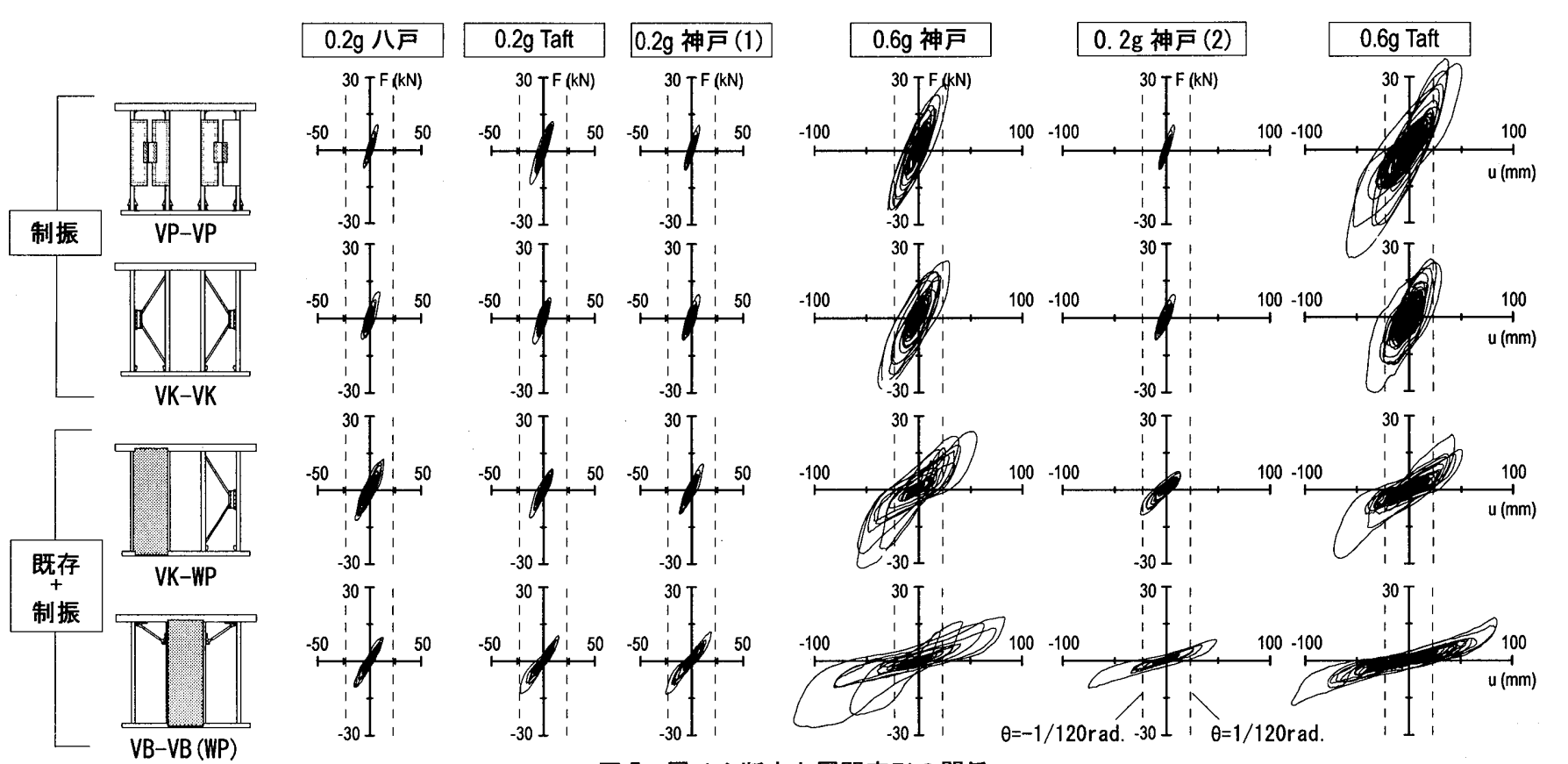

図 5 層せん断力と層間変形の関係

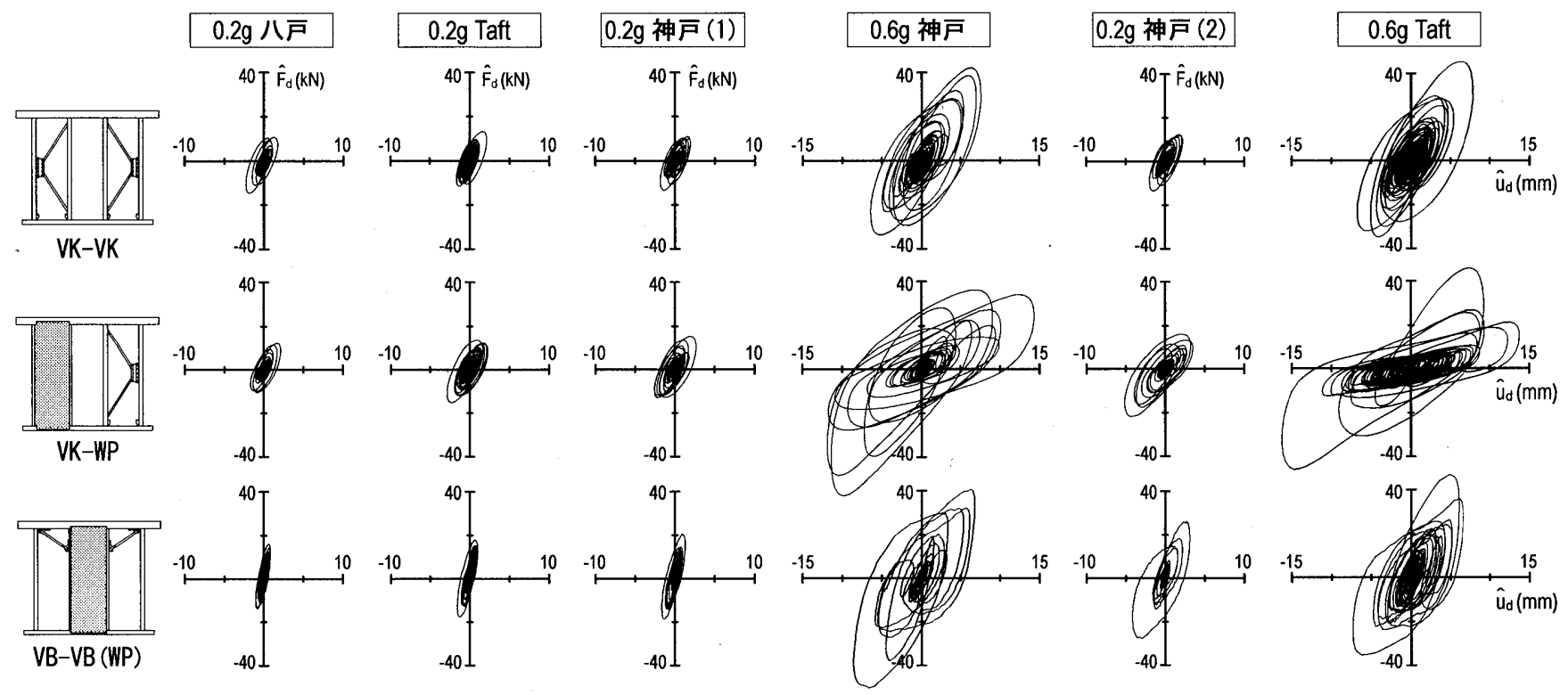

图 6 ダンパーカとダンパー変形の関係

く変形した。このため、0.2g 神戸波(2 回目)では WP 部の剛性が著し く低下し、方杖ダンパーの効率が低下し大きく変形した。

\section{4. 局所応答}

\section{1 ダンパーのカと変形の関係}

図 6 に、各ダンパー可動方向の力 $\hat{F}_{d}$ と変形 $\hat{u}_{d}$ の関係を示す。制 振壁が 2 構面組み込まれた試験体では、その履歷形状がほぼ一致 したため、片側の制振壁のダンパーのみに言及する。

$\mathrm{VK}-\mathrm{VK}$ 試験体の粘弹性ダンパーは $0.2 \mathrm{~g}$ の各 3 波で棈円の履歴を 示したことから小振幅の入力に対しても機能していることが分かる。 $0.6 \mathrm{~g}$ 神戸波では、入力中に温度が上昇したため等価剛性がやや低下 している。また、 $0.2 \mathrm{~g}$ 神戸波( 2 回目) では 1 回目と履歷が同じであ ることから $0.6 \mathrm{~g}$ 神戸波入力時にもダンパー自身に損傷は無かった と言える。0.6g Taft 波においてもダンパー自身の損傷は無かった。

VK-WP 試験体の粘弾性ダンパーは、 $0.2 \mathrm{~g}$ の各 3 波で VK-VK と同
様に楕円の履歴を示した。等価風性も同様であったことから、粘弾 性ダンパーが有効に機能したと言える。 $0.6 \mathrm{~g}$ 神戸波ではせん断歪 $500 \%$ に相当する $15 \mathrm{~mm}$ 程度まで変形し、エネルギー吸収量を示す楕 円の面積も VK-VK よりも大きく、ダンパー温度が急激に增加した ことからダンパーの貯蔵剛性が低下した ${ }^{7)}$ 。また、その後の $0.2 \mathrm{~g}$ 神 戸波(2 回目)の入力ではダンパーの貯蔵剛性が 1 回目よりも下がっ ていることから、ダンパー自身に損傷が生じていることがわかる。

VB-VB(WP)試験体の粘弾性ダンパーは、 $0.2 \mathrm{~g}$ の各 3 波で棈円の履 歴を示すものの、 $\mathrm{K}$ 型ダンパーと比べて $\hat{F}_{d}$ が高いことから、ダンパ 一の効率が低いといえる。0.6g の入力では最大で約 $50 \mathrm{kN}$ のダンパ 一力が生じ、それを柱 1 本のみで受け持つとした時には、柱 1 本の 曲げ強度を越えることになるが、隣に併設している構造用合板が効 果的に機能したため、柱に損傷はみられなかった。また、ダンパー に引張荷重が作用した場合にも付録 2 に示したピン治具に損傷は見 られなかったことから、ビスが効果的に機能したことがわかる。 


\section{2 粘弾性ダンパーの温度の時刻歴}

粘弾性体は外力仕事を分子運動により熱エネルギーに変換する材 料であり、ある時点での温度上昇量はそれまでの総エネルギー吸収 量を粘弾性体の比熱と密度の積で割ることにより求められる ${ }^{5)}$

計算により求めたダンパー温度と実験值との比較として、図 7 に 神戸 $0.6 \mathrm{~g}$ 入力時における VK-VK, VK-WP試験体のダンパー温度の時 刻歴と、その時のダンパー変形(細い線)を示す。 $\mathrm{t}=5[\mathrm{sec}]$ 付近から粘 弾性体の変形と共に温度が急激に上昇し始め、その後の約 5 秒間は 計算值と実験值が概ね一致していることがわかる。 $\mathrm{t}=10[\mathrm{sec}]$ 付近か らは粘弾性体の変形が小さくなるため、計算値の温度は緩やかに上 昇寸るが、実験值の温度は外気による粘弾性体の冷却効果の影響が 強くなるため徐々に下降する。以上のことから、長時間継続する地 震波の時刻歷応答解析を厳密に行う場合、ダンパー冷却の影響によ る粘弾性体の温度低下も考虑に入れる必要があることがわかる。

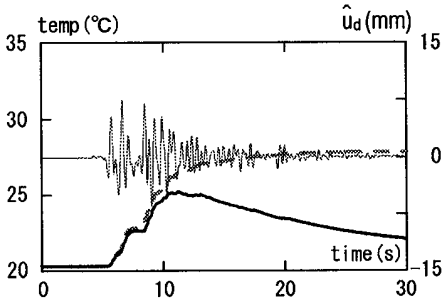

(a) $V K-V K$

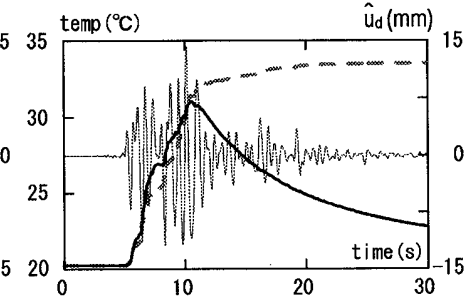

(a) VK-WP
図 7 神戸 $0.6 \mathrm{~g}$ 入力時におけるダンパー温度と変位の時

\section{3 柱脚の軸力と変形の関係}

図 8 に、 $0.6 \mathrm{~g}$ 神戸波における引き寄せボルト引張力と柱浮き上が り量の最大值を示す。柱は図の左より(1)〜(4)とする。図中の破線は、 アスペクト比 3 と壁要素 $2 \mathrm{P}$ をふまえ、層せん断力の最大值 $F_{\max }$ を $3 / 2$ 倍した值、つまり 2 枚の壁要素が同等にせん断力を負担し、か つ壁頂部の回転拘束がない場合の各脚部の転倒モーメントによる軸 力の推測值である。

VP-VP 試験体の引き抜け量が小さいことから、引き寄せ金物を柱 の両側に配した接合部の剛性の高さが確認できる。また、全ての柱 の最大引張力が $1.5 F_{\max }$ に近いことから引張力のほとんどを引き寄 せボルトが負担していることがわかる。

VK-WP 試験体からは VK 部の柱の引張力が WP 部の柱の引張力よ り大きいにもかかわらず、柱の引抜け量は VK 部の方が WP 部より も小さいことから K 型架構の引き寄せ金物は一般の引き寄せ金物よ

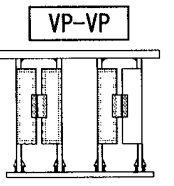

(1) (2) (3) (4)

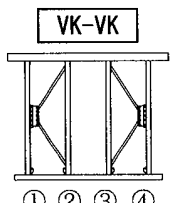

(1) (2) (3) (4)

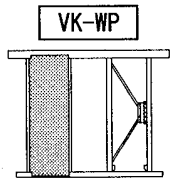

(1) (2) (3) (4)

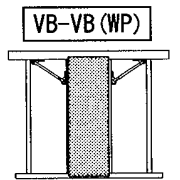

(1) (2) (3) (4)
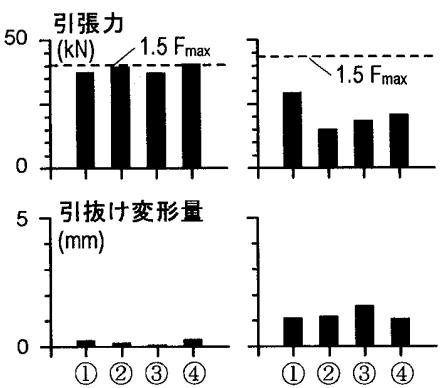

(1) (2) (3) (4)

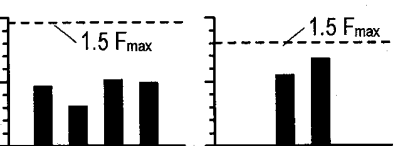

図 8

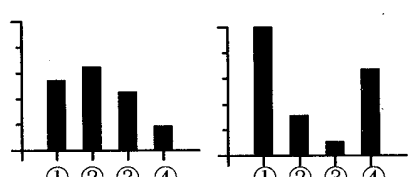

引張力と柱脚引技け

り高性能であることがわかる。

VB-VB(WP)試験体は外側の柱にホールダウン金物を取り付けて いないため、外側柱の引抜け量が大きくなった。

\section{4 ダンパーのカと変形の分担}

壁要素の柱・横架材接合部をピンと仮定した場合、壁要素のアス ペクト比が 3 であることから、2つのダンパーに働くせん断力の和 は架構のせん断力の 3 倍となり、ダンパーの変形は層間変形の $1 / 3$ 倍となる。実際には接合部のピン仮定は成立せず、接合部の引き抜 け等によるダンパー変形の低减や、接合部の曲げ抵抗等による架構 の耐力上昇があるため、本架構はエネルギー吸収能力のバランスを

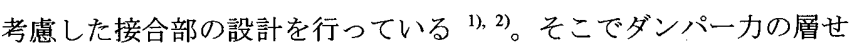
ん断力に対する寄与分と、ダンパー変形の層間変形に対する変形効 率に関して考察する。

図 9 に $0.2 \mathrm{~g}$ 神戸波( 1 回目)、0.6g 神戸波入力時の層せん断力 $F$ と 層間変形 $u$ のダンパー寄与分を時刻歴で示す。ダンパーカの寄与分 はダンパーカの和を $1 / 3$ 倍、ダンパー変形の寄与分はダンパー変形 の 3 倍としている。試験体は VK-VK 試験体と、比較のために文献 3 の FK-FK 試験体も示している。FK 架構は K 型ブレースのダンパー 部に摩擦ダンパー(Friction)を用いた試験体である。

層せん断力に注目すると、0.2g 神戸波(1 回目)において、VK-VK 試験体ではダンパー力が層せん断力の 9 割弱を負担しているのに対 し、FK-FK 試験体では層せん断力のほぼ全てを負担しているといえ る。これはダンパー部の初期剛性の差による影響であり、FK-FK 試 験体はダンパー部以外の架構の初期剛性と比べてダンパー部の初期 剛性が高いためである。 $0.6 \mathrm{~g}$ 神戸波入力ではダンパーの負担するせ ん断力が架構の負担するせん断力に比べて大きくなるため、どちら の試験体も層せん断力のほぼ全てを負担している。一方、層間変形 に注目すると、VK-VK 試験体は $0.2 \mathrm{~g}$ 神戸波 $(1$ 回目)、 $0.6 \mathrm{~g}$ 神戸波共
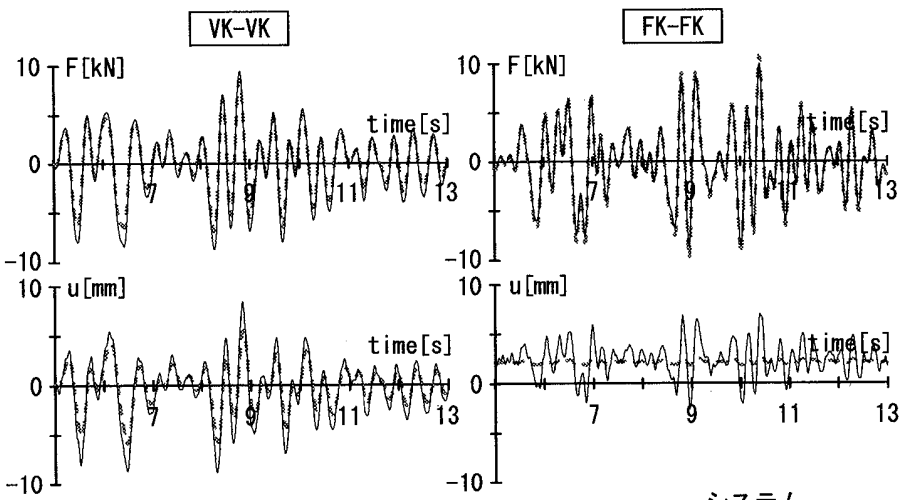

(a) $0.2 \mathrm{~g}$ 神戸波 (1 回目) - - タタンハパー寄与分

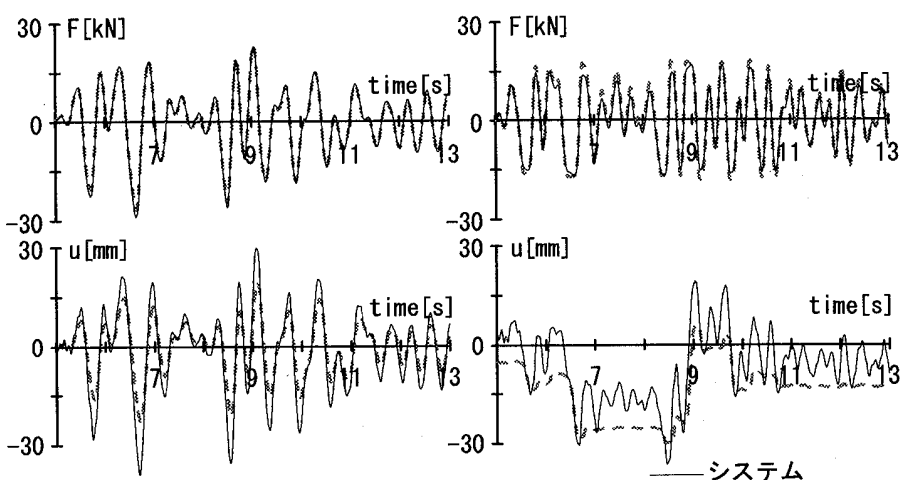

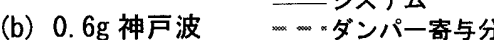

図 9 層せん断力と層間変形のダンパー寄与分の時刻歴 
に一定の割合で層間変形に寄与している。これに対し、FK-FK 試験 体は $0.2 \mathrm{~g}$ 神戸波(1 回目)ではほとんど変形せず、0.6g 神戸波入力で は架構が大きく変形するときに、ダンパー部にはすべり荷重を超え たダンパーカが発生し、ダンパー部がすべることによって架構の変 形に追従するように変形はするものの、架構が微小な変形をすると きにダンパー部はほとんど変形しない。すなわち、このときはダン パー部以外の架構の弾性変形が生じている。

このことからも、粘弾性ダンパーは小変形から大変形までの広い 範囲において安定したエネルギー吸収能力を示寸のに対し、変位依 存ダンパーでは大変形時のみに制振性能を示すことが確認できる。

\section{5. 剛性と減衰の傾向}

\section{1 エネルギー吸収能力}

図 10 は、各地震波の入力終了までの、試験体とダンパーのエネル ギー吸収量を加振ごとに示している。試験体全体のエネルギー吸収 量は層せん断力-層間変形の履歴面積(図 5) から、ダンパーのエネル ギー吸収量は各ダンパーの履歷面積(図 6) の合計から評価した。な お、VP-VP 試験体においてはダンパー荷重を計測できないため、架 構全体のエネルギー吸収量のみ示す。

VP-VP 試験体の全体のエネルギ一吸収量は、0.6g 神戸波入力では 他の試験体より少なく、0.6gTaft 波では他の試験体より多い。これ は加振の都合上 $0.6 \mathrm{~g}$ 神戸波では目標よりも入力加速度が小さくな り、0.6gTaft 波では目標よりも入力加速度が大きくなったためであ る。VK-VK 試験体は、入力に関わらず全体に対するダンパーのエネ ルギー吸収量が一定で、ダンパーが全体に対して約 7 割のエネルギ 一を吸収した。文献 3 で示した変位依存ダンパーの制振試験体と比 較すると、粘弾性を有する試験体は小振幅時のエネルギ一吸収に長 けていることが分かる。この傾向は他の試験体においても同様で、 全体に対するダンパーのエネルギー吸収量が VK-VK 試験体よりは 低いものの、全体の吸収エネルギーに対してVK-WP 試験体で約 6 割、VB-VB(WP)試験体で約 5 割のエネルギーをダンパーが吸収した。 $W(k N \cdot m)$

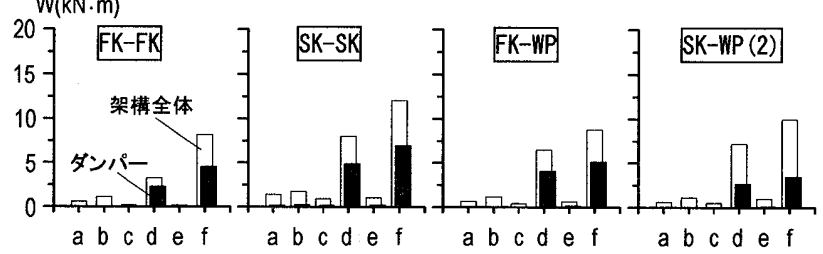

(a) 変位依存ダンパー

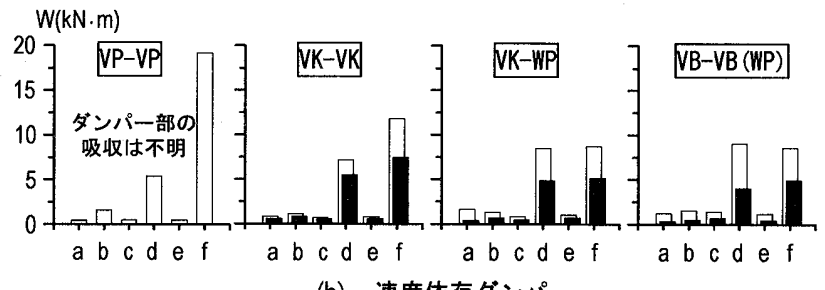

(b) 速度依存ダンパー

図 10 架構全体とダンパーのエネルギ一吸収 $(\mathrm{a}=0.2 \mathrm{~g}$ 八戸, $\mathrm{b}=0.2 \mathrm{gTaft}, \mathrm{c}=0.2 \mathrm{~g}$ 神戸 1 回目， $d=0.6 \mathrm{~g}$ 神戸, $e=0.2 \mathrm{~g}$ 神戸 2 回目, $f=0.6 \mathrm{gTaft}$ )

\section{2 微小変形時の周期と減衰}

地震波の入力前後には最大加速度 $0.1 \mathrm{~g}$ のホワイトノイズ波を入 力している (表 2)。応答は層閒変形で $1 / 900 \mathrm{rad}$. 以下と非常に小さく、 よって線形と仮定できると考え、土台加速度から桁頂部加速度への 伝達関数と概ね一致する伝達関数をもつ線形一質点系の固有周期と
減衰定数を、試験体の微小変形時における固有周期・減衰定数 $T_{0}, h_{0}$ と定義した。以上より、各地震波入力後の試験体の特性の変化を把 握した。図 11 に、ホワイトノイズ W1〜W7（表 2）の入力より算出 した固有周期 $T_{0}$, 減衰定数 $h_{0}$, 粘性減衰係数 $C_{0}$ を示す。比較のため、 文献 3 の試験体も含めてある。

図 11 左列は文献 $3 て ゙$ 記述した既存耐力壁の試験体の特性を示して いる。0.6g 神戸波・0.6gTaft 波の入力により $T_{0}$ の值が上昇し、それ に伴い $h_{0}$ の值も上昇するが、それらは等価剛性が低下したことによ るものであり、その時の $C_{0}$ は減少しているため、エネルギー吸収能 力の低下が起こっていることに注意する。

一方、制振壁の等価周期・減衰定数 $T_{0}$ と $h_{0}$ の傾向は、以下の如 くである (図 11 中列)。VP-VP, VK-VK 試験体は入力波に関わらず $T_{0}$ と $h_{0}$ がほぼ一定であることから、本論で用いた制振壁の場合、架 構に損傷がほとんどないことが予測できる。また、文献 3 の変位依 存ダンパー制振試験体と比べ $h_{0}$ と $C_{0}$ が常に高いことから、微小変 形においても粘弾性ダンパーが有効に機能していることが分かる。

既存耐力壁と制振壁の両方をもつ試験体において（図 11 右列）、 VK-WP 試験体は、0.6g 神戸波の入力後、合板の釘の緩みにより $T_{0}$ と $h_{0}$ が大きくなった。また、C $C_{0}$ の值に大きな変化がないことから、 エネルギ一吸収能力は低下していないことがわかる。VB-VB(WP) 試験体においては既存耐力壁と同様の傾向を示しており、ダンパー の効率としては低いといえるだろう。

地震波による大变形時の特性に関しては様々な算出法で抽出した が、それを用いて線形スペクトルから応答予測しても、線形的な挙 動となる場合は良い精度を示すものの、非線形的な挙動となるほど 精度は悪くなった。従って、6 章で示す応答スペクトルによる予測 法で検討を行う。応答スペクトルによる予測法は経験に基づくもの だが、良い精度を示すものと考えられる。
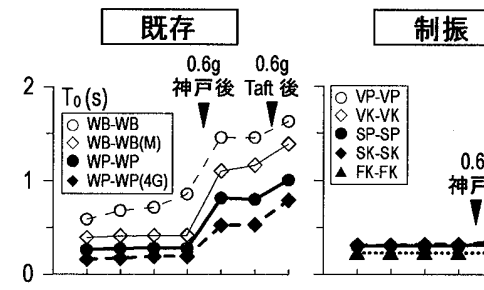

制振+既存
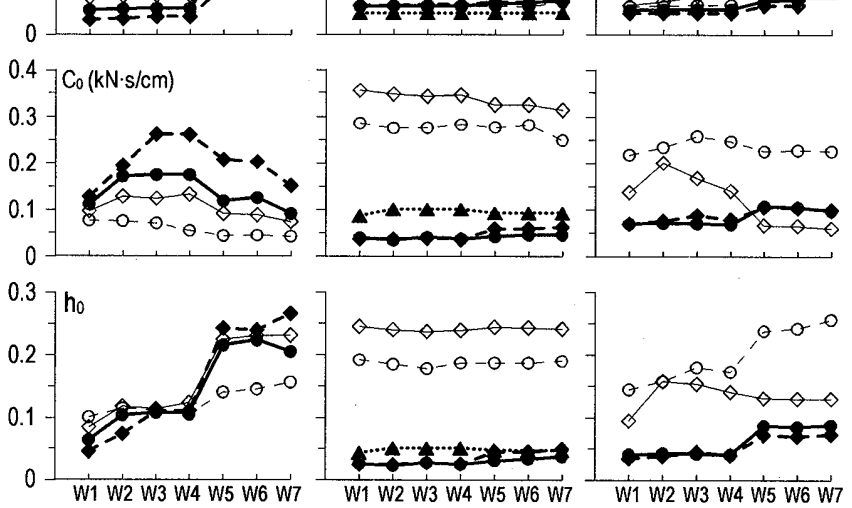

図 11 固有周期と粘性減衰の変動特性（微小変形時）

\section{6. スペクトル解析による応答予測}

文献 3 でスペクトル解析を用いて弾塑性ダンパーを有する試験体 の最大応答を予測できることを示した。ここでは、既存耐力壁およ び粘弾性ダンパーを有する試験体に関しても、スペクトル解析を行 い予測值と実験值との比較検討を行う。応答スペクトルで包括的 な傾向を把握することは、設計を行う際に有用である。 
6. 1 既存酎カ壁による試験体の応答予測

構造用合板による試験体の忘 答予測の流れは文献 3 と同様とす る。しかし、構造用合板による試 験体の履歴は弾塑性ではなくスリ ップ形となるため(図 12)、等価减 衰定数の算出が異なってくる。す なわち、塑性率 $\mu$ ’を示すサイクル における等価減衰定数 $h^{\prime}{ }^{\prime}\left(\mu^{\prime}\right)$ は、 履歴吸収エネルギーと弾性エネル

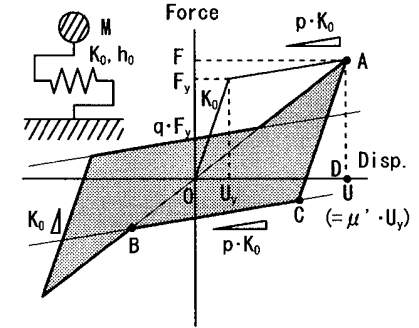

図 12 スリップ履歴特性の定義
ギ一の比から式(1)のように求められる。さらに、文献 8,9 の Newmark-Rosenblueth 式と同様の概念で、 $h^{\prime}{ }_{\text {eq }}\left(\mu^{\prime}\right)$ を $\mu^{\prime}$ に対して 0 か ら最大值 $\mu$ まで平均化することにより、等価減衰定数を式(2)のよう に得る。その時の等価周期は式(3)として求まる。ただし、初期减衰 定数 $h_{0}$ は 0.05 、スリップ時の剛性は二次剛性 $\left(p \cdot K_{0}\right)$ 、スリップ時の $\mathrm{y}$ 切片は $q \cdot F_{y} 、 \mu$ は 1 以上とする。

$$
\begin{aligned}
& h_{e q}{ }^{\prime}\left(\mu^{\prime}\right)=h_{0}+\frac{1}{2 \pi} \cdot \frac{\triangle A B C}{\triangle A O D}=h_{0}+\frac{\left(\mu^{\prime}-1\right)(1-p+q)^{2}}{2 \pi \mu^{\prime}(1-p)\left(1-p+p \mu^{\prime}\right)} \\
& h_{e q}=\frac{1}{\mu} \int_{0}^{\mu} h_{e q}{ }^{\prime}\left(\mu^{\prime}\right) d \mu^{\prime}=h_{0}+\frac{(1-p+q)^{2}}{2 \pi \mu(1-p)^{2}} \ln \frac{(1-p+p \mu)}{\mu^{p}} \\
& T_{e q}\left(\mu^{\prime}\right)=T_{0} \sqrt{\frac{\mu}{1-p+p \mu}}
\end{aligned}
$$

塑性率 $\mu$ での最大変位 $U$ と最大せん断力 $F$ は、式(4), (5)を用い、 弾性系の最大変位 $U_{e l}$ と最大せん断力 $F_{e l}$ を基準に、木質架構が該当 する加速度一定領域では以下のように予測できる。

$$
U=U_{e l} D_{h} \frac{T_{e q}}{T_{0}} \cdot \frac{T_{e q} / T_{0}+1}{2}, \quad F=F_{e l} \frac{U}{U_{e l}}\left(\frac{T_{e q}}{T_{0}}\right)^{2}
$$

ここに $D_{h}$ は減衰定数を $h_{0}$ から $h_{e q}$ に変化させた場合の減衰による 応答低減を加味する減衰効果係数で、以下の式で表される。

$$
D_{h}=\sqrt{\left(1+25 h_{0}\right) /\left(1+25 h_{e q}\right)}
$$
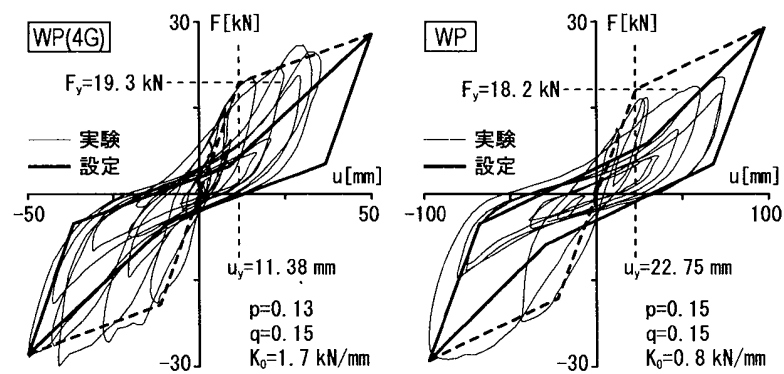

図 13 係数の設定(スリップ履歴)

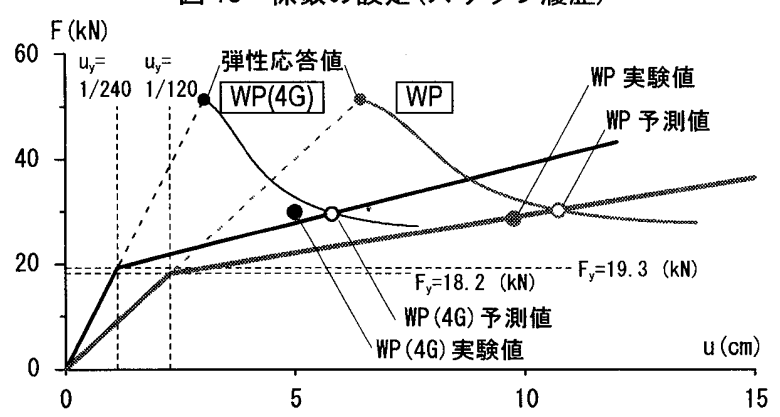

図 14 構造用合板を持つ架構の最大応答予測值と実験値
式(6)が実地震波の統計的な精度を良く表すことは、筆者らの研究 より明らかである ${ }^{10)}$ 。試験体の一次固有周期は基準法スペクトル 11) の加速度一定領域にあたり、入力した $0.6 \mathrm{~g}$ の地震波の減衰定数 $3.3 \%$ における擬似加速度応答スペクトルは、その領域において平均 で $1.6 \mathrm{~g}$ となる。基準法スペクトルでの加速度応答 $1.1 \mathrm{~g}$ をレベル 2 とすれば $1.6 \mathrm{~g}$ はその約 1.5 倍にあたり、よって入力した $0.6 \mathrm{~g}$ の地震 波はレベル 3 相当とみなすことができる ${ }^{3)}$ 。また、式(6)を用いるこ とで $h_{0}=0.05$ での擬似加速度応答スペクトルは、平均で $1.44 \mathrm{~g}$ となる。 WP-WP, WP-WP(4G)試験体における各係数は以下のように定めた (図 13)。0.6g 神戸波入力時の履歴を用い、WP-WP では降伏変形 $U_{y}$ を 1/120rad. $(=22.75 \mathrm{~mm}) 、 W P-W P(4 \mathrm{G})$ では $U_{y}$ を 1/240 rad. $(=11.38 \mathrm{~mm})$ と設定し、その時の正負のせん断力の平均から初期剛性 $K_{0}$ を算出し た。これは WP-WP(4G)の場合、石膏ボードの影響で降伏変位が小さ くなることに起因している。二次剛性比 $p$ は最大層せん断力および 最大変形が一致するように、スリップ耐力比 $q$ は履歷曲線にフィッ ティングさせることで求めた。

それらを用いて式(1)〜(6)にあてはめることで変位・加速度の低減 効果を示す曲線を得る(図 14)。各耐力壁の復元力特性は図中太線の ようになる。白丸が示すように、これらの交点で試験体の最大変位・ せん断力が予測され、黒丸は対応する実験結果である。

WP-WP(4G)試験体は石膏ボードが初期変位から層せん断力を負 担し、初期剛性が高いことから変形が小さくなっていることがわか る。また、両者の降伏せん断力はほぼ等しいため、最大耐力にはほ とんど差が生じていないことがわかる。この応答予測法に対して多 数の検証を行ったわけではないが、両者とも予測值と実験值が概ね 一致していることから、スリップ履歴を有する建物に対しても展開 できる可能性を示しているといえるだるう。

6. 2 粘弾性ダンパーによる試験体の応答予測と制振効果の概念

粘弾性ダンパーを用いた VP-VP, VK-VK 試験体の最大応答を、架構 の等価周期と等価減衰定数に基づ き考察・検討する。VK-VK 試験体 の地震時の履歴に対して最小二乗 法を用いることで、等価剛性 $K_{e q}$, 等価減衰定数 $h_{e q}$ を求められる ${ }^{12}$ 。 それらを用いた 1 質点時刻歷解析 と実験值はよく一致する(図 15)た

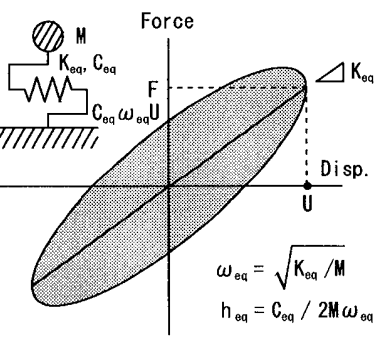

図 16 粘弾性履歴特性の定義
め、試験体を図 16 のような線形システムとして仮定できる。 $0.6 \mathrm{~g}$ 神戸波入力時の履歷から、同様に最小二乗法で求まる $K_{e q}, h_{e q}$ は、図 17 に示すと㧍り、実験值と非常に良い対応を示している。

ここで、線形システムにおいては式(7)が成り立つ。

$$
U=D_{h}\left(T_{e q} / 2 \pi\right)^{2} S_{p a}\left(T, h_{0}=0.05\right)
$$

前節と同様に、加速度応答スペクトルは $1.44 \mathrm{~g}$ で一定であること から、式(5)〜(7)を用いることにより図 18 の予測值を得る。なお、 VP-VP は加振の都合上 $0.53 \mathrm{~g}$ しか入力されていない。そのため、実 験值の層せん断力および層閒変形は 1.13 倍 $(=0.60 / 0.53)$ している。

VK-VK 試験体は、VP-VP 試験体に比べ等価剛性は低いものの、 等価減衰定数も大きいため、変位応答が小さく収まったことが分か る。また、この応答低減率を用いた予測值と実験值はよく一致して いる。よって、この予測法が粘弾性体を用いた 1 層木質制振架構を 十分評価できると言える。 
加速度応答スペクトルは一定と仮定されていることから、等価減 衰定数が等しければ、架構の周期に関わらず層せん断力は等しくな る。等価减衰定数を初期減衰定数 $h_{0}=0.05$ から $h_{e q}=0.10,0.20,0.35$ と 増加させると、忘答変位、応答加速度(層せん断力)ともに $h_{0}=0.05$ 時 の值にその応答低减係数を乗じた值、つまり $0.80,0.61,0.48$ 倍に減 少する。一定の変形以内に留めるためには、剛性を高めるか減衰を 高めるかのどちらかであるが、変位応答は周期の 2 乗に比例し、ま た、前者の場合において加速度応答(層せん断力)が大きくなること もふまえると、粘弹性を用いた制振架構を設計寸る際には過度に等 価周期を短くするのではなく、減衰定数を高める心゙きである。
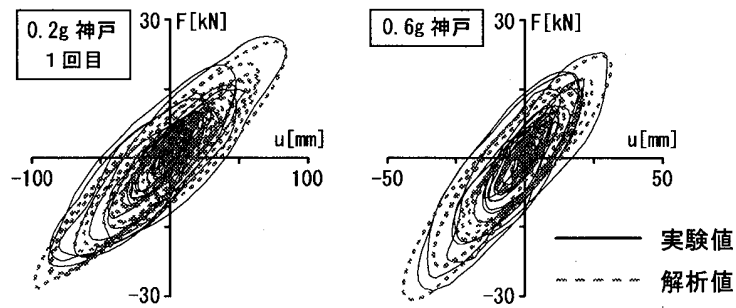

図 15 一質点時刻歴解析と実験值の比較
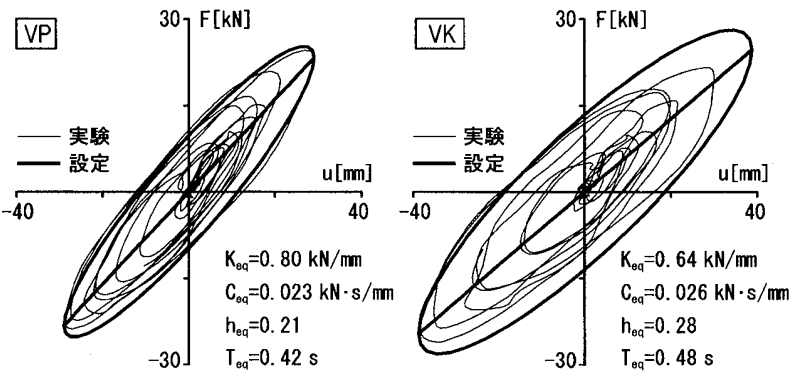

図 17 係数の設定（粘弾性履歴）

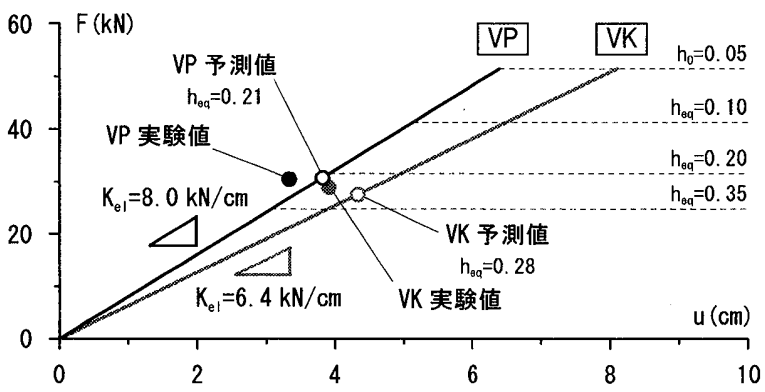

図 18 粘弾性ダンパーを持つ架構の最大応答予測值と実験値

7. まとめ

筆者らが開発した制振壁を組み込んだ実大試験体の振動台実験 により制振壁の有効性を立証した。以下にまとめる。

（1）制振壁を用いることでレベル3相当の地震でも部材・接合部を 守り、加振前とほぼ同じ動的特性を保つことが可能である。

(2) 粘弾性ダンパーは变位依存ダンパーと異なり、微小変形におい ても優れたエネルギ一吸収能力を示す。

（3）粘弾性ダンパー方杖型は、開口部にも設置可能な小型のダンパ 一であるため、実際の住宅にはさらに多く設置することでより良い制 振性能を得ることができる。

（4）最大応答の予測は、前報 ${ }^{3)}$ 含めることで変位依存ダンパー・ 速度依存ダンパー・既存耐力壁のどれを有する場合でも、提案した 手法 ${ }^{10)}$ で簡便にかつ良好な精度で行うことができると考えられる。
本論文は、平成 15 年度国土交通省建設技術研究開登費補助金の助成による プロジェクト「財産保持性に優れた戸建制振住宅に関寸る研究開発（研究代 表者：笠井和彦)」の成果の一部を報告した。また、信州大学助教授 五十田 博氏、(社)日本免震構造協会 永井潔氏には貴重なご助言を頂きました。試験 体の作成には(株)カナイ常務取締役 並木高氏、(株)住宅構造研究所 金井健二 氏にご尽力頂きました。ここに記して深謝致します。

\section{参考文献}

1) 坂田弘安, 笠井和彦, 和田章, 宮下健: 合板パネルによるシアリンク制振 機構を用いた木質架構の動的举動に関する実験研究，日本建築学会構造系 論文集，第 594 号, pp. 65-73, 2005.8

2) 笠井和彦, 坂田弘安, 和田章, 宮下健: $K$ 型ブレースによるシアリンク制振 機構を用いた木質架構の動的挙動，日本建築学会構造系論文集，第 598 号， pp. 51-60, 2005.12

3) 笠井和彦, 和田章, 坂田弘安, 緑川光正, 大木洋司, 中川徹: 变位依存ダン パーをもつ木質架構の振動台実験，日本建築学会構造系論文集，第 594 号， pp. $101-110,2005.8$

4) 笠井和彦, 寺本道彦, 大熊潔, 所健 : 粘弹性体の温度・振動数・振幅依存を 考慮した構成則 (その 1 線形領域における温度・振動数依存のモデル化), 日本建築学会構造系論文集, 第 543 号, pp.77-86, 2001.5

5) 笠井和彦, 所健: 粘弹性体の温度・振動数・振幅依存を考慮した構成則 (そ の 2 温度上昇および歪・歪速度がもたらす非線形性のモデル化), 日本建 築学会構造系論文集, 第 561 号, pp. 55-63, 2002.11

6) 笠井和彦，大木洋司，雨宫健吾，木村勝彦：イソブチレン系粘弹性体の温 度・振動数・振幅依存性を考慮した非線形力学モデルの構筑, パッシブ制 振構造シンポジウム論文集 2002,pp.181-194, 2002.12

7) 所健, 笠井和彦, 大熊潔: 粘弾性体の破壊挙動に関寸る実験的研究 日本建 築学会大会学術講演梗概集, pp.315-316, 2001.9

8) Newmark, N.M. and Rosenblueth, E. "Fundamentals of Earthquake Engineering." Prentice-Hall Inc., 1971

9) Iwan, W.D. and Gates, N.C. "Estimating Earthquake Response of Simple Hysteretic Structures." Jounal of the,Earthquake Mechanics Division, ASCE, pp.391-405, 1979

10)笠井和彦, 伊藤浩資, 渡边厚: 等価線形化手法による一質点系弾塑性構造 の最大応答予測法，日本建築学会構造系論文集，第 571 号，pp. 53-62, 2003.9

11)木造軸組み構法建物の限界耐力計算による耐震設計・耐震補強設計マニュ アル，日本建築総合試験所 木造軸組み構法建物の限界耐力計算による耐 震設計法編集委員会, 2003.7

12)笠井和彦, 大熊潔: 振動数に依存する制振構造の等価周期・減衰定数の評 価法とその精度，日本建築学会構造系論文集，第 580 号, pp. 51-59, 2004.6

\section{付録 1 壁倍率の算定}

壁倍率は、特定変形角時強度、降伏強度、最大耐力の $2 / 3$ の強度、および 終局耐力と勒性から決まる値の最小値に上り決定されるが、本報では特定変 形角( $1 / 120 \mathrm{rad}$.$) 時の強度のみを用いて壁倍率と称している。$

付録 2 強制変形加振実験におけるVB 試験体詳細および実験結果

VB 試験体の詳細を図 A-1 に示す。ダンパー 端部の詳細は振動台実験と同様である。実際に 使用寸る際は、振動台実験の上うに VB架構の 隣に合板の耐力壁や内外装材が配置されるこ とを想定し、ダンパー端部が取り付く側の柱 (図中の左柱)を柱と同断面の角材と $3.2 \mathrm{~mm}$ 厚 の鋼板で補強してある。イソブチレン・スチレ ン系の粘弹性体を $\phi 42.7 \mathrm{~mm}$ と $\phi 34 \mathrm{~mm}$ の鋼管の 間に溶着し、ダンパーを製作した。ダンパー端 部はピン接合にし、ダンパーには純粋な軸方向 カだけが作用守る。ピンの治具杜柱・梁に效し て M6 のビス計 20 本で固定され、ダンパーカ

に対して十分な引抜・せん断耐力を有する設計となっている。

図 A-2 に、VB架構単体の強制変形加振実駼加得られた層せん断力と層間 変形の関係を示す。この履歴曲線は層間変形角 $\pm 1 / 30 \mathrm{rad}$ までの結果であり、 試験方法は文献 1,2 で述べた制振壁の強制変形加振実験と同様である。

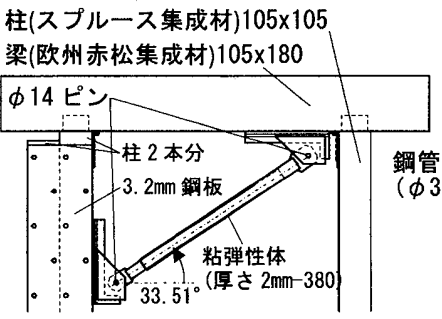

(a) ダンパー部立面

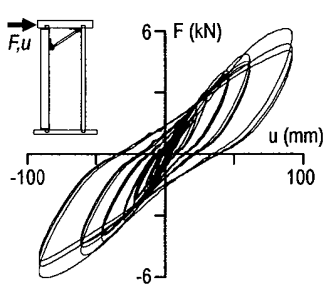

图 $A-2 \quad V B$ 試験体の履歴曲線
図 A-1 1P の強制変形加振実験における VB 試験体詳細 